\title{
Controlled Growth of Multi-walled Carbon Nanotubes Using Arrays of Ni Nanoparticles
}

\author{
Seungmuk Ji ${ }^{1}$, Taejin Lee ${ }^{1}$, Jae Ho Bahng ${ }^{2}$, Young-Kyu Hong ${ }^{2}$, Hanchul Kim², Dong Han $\mathrm{Ha}^{2}$, \\ Chang-Soo $\mathrm{Kim}^{2}$, and Ja-Yong $\mathrm{Koo}^{2^{*}}$ \\ ${ }^{1}$ Department of Physics, Kangwon National University, Chuncheon, Kangwon 790-784, Korea \\ ${ }^{2}$ Korea Research Institute of Standards and Science, P.O.Box 102, Yuseong, Daejeon 305-600, Korea
}

(Received June 9 2008, Revised August 28 2008, Accepted August 28 2008)

\begin{abstract}
We have investigated the optimal growth conditions of carbon nanotubes (CNTs) using the chemical vapor deposition and the Ni nanoparticle arrays. The diameter of the CNT is shown to be controlled down to below $20 \mathrm{~nm}$ by changing the size of Ni particle. The position and size of Ni particles are controlled continuously by using wafer-scale compatible methods such as lithography, ion-milling, and chemical etching. Using optimal growth conditions of temperature, carbon feedstock, and carrier gases, we have demonstrated that an individual CNT can be grown from each Ni nanoparticle with almost $100 \%$ probability over wide area of $\mathrm{SiO}_{2} / \mathrm{Si}$ wafer. The position, diameter, and wall thickness of the CNT are shown to be controlled by adjusting the growth conditions.
\end{abstract}

Keywords : Carbon nanotube, Controlled growth, Nanoparticle, Chemical vapor deposition.

\section{I . Introduction}

The carbon nanotube (CNT) [1] is one of the most studied nanostructured materials for its excellent electrical and mechanical properties [2]. While multiwalled CNTs (MWNTs) show complicated electrical properties, single-walled CNTs (SWNTs) are either metallic or semiconducting depending on the atomic structure [3,4]. Utilizing such electrical properties, SWNTs have been applied to demonstrate single device performance including field-effect transistor [5], random access memory [6], room-temperature single-electron transistor [7], and logic gates [8-10].

Though the feasibility of individual devices has been demonstrated till now, the mass production of the practical CNT-based integrated devices requires to develop extreme control technologies. For example, CNTs of well-defined diameter, wall thickness, direction, length, and chirality should be placed at desired locations over wide area, with $100 \%$ probability, and at high speed compatible with the current $\mathrm{Si}$ industry.

There have been many efforts to achieve such a controllability. Placement of individual CNTs has been tried in several ways such as the attachment on functionalized patterns utilizing chemical interactions [11-13] or the electric-field-assisted trapping in the small gap between two electrodes [14,15]. The direction of CNTs on a substrate could be controlled by applying the electric field during the growth [16-18]. The

* [E-mail]koojayon@kriss.re.kr 
diameter of CNTs was shown to be controlled by changing the size of catalytic nanoparticles [19-22]. In that perspective, metallic nanoparticles smaller than $10 \mathrm{~nm}$ were shown to be distributed within specific patterns over wide area with controlled density [23]. MWNTs thicker than $50 \mathrm{~nm}$ were directly grown from catalytic seed particles by plasma-enhanced chemical vapor deposition (CVD) [24,25], and SWNTs were also grown from ordered $\mathrm{Co}$ and $\mathrm{Fe}$ nanoparticles fabricated by electron beam lithography [26]. However, all these methods are yet far from the practical technology for mass production of CNT-based integrated devices.

In this work, we propose a simple and reliable method to grow multi-walled carbon nanotubes (MWNTs) in a controlled manner. The location and the size of MWNTs are controlled by using arrays of catalytic Ni particles which are positioned by lithography and reduced in size by ion-milling and chemical etching. Under the optimal growth conditions found in this work, an individual MWNT is grown from each $\mathrm{Ni}$ nanoparticle with almost $100 \%$ probability. The diameter and the wall thickness of the MWNTs can be controlled by adjusting growth conditions. The proposed procedure is compatible with the current silicon technology, and can be a useful step forward to the realization of integrated circuits of CNTs.

\section{П. Experiments}

We choose thermal CVD in growing CNTs since it is simple and convenient for the mass production. We need at least three essential ingredients in the CVD growth of CNTs. (i) We use the ethylene $\left(\mathrm{C}_{2} \mathrm{H}_{4}\right)$ gas as the carbon feedstock, for its low dissociation probability at high temperature makes it easier to control the growth of small-diameter CNTs, compared with $\mathrm{C}_{2} \mathrm{H}_{2}$. [22] (ii) We use nano-sized Ni particles as the catalytic seed. (iii) The 1:1 mixture of $\mathrm{H}_{2}$ and $\mathrm{Ar}$ is used as the carrier gas to control the concentration of the $\mathrm{C}_{2} \mathrm{H}_{4}$ gas.

Firstly, we tried to establish the optimal growth condition of CNTs by varying four independent parameters - the size of catalytic particles, the growth temperature, the flow rate of $\mathrm{C}_{2} \mathrm{H}_{4}$, and the flow rate of $\mathrm{H}_{2}$ and Ar. For that purpose, it is
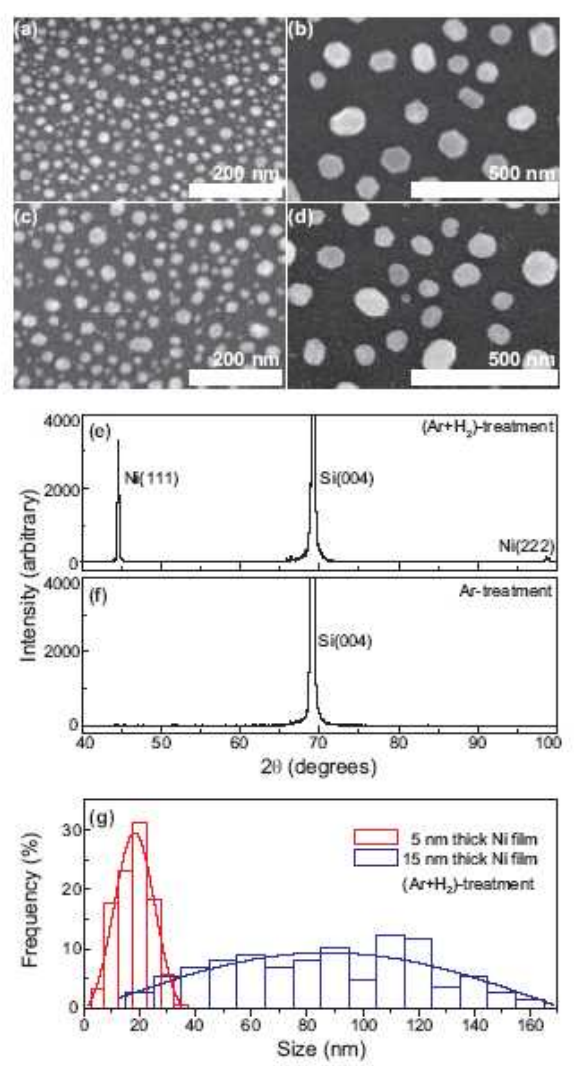

Fig. 1. The SEM images of Ni particles formed at 850 ${ }^{\circ} \mathrm{C}$ for 30 min under $200 \mathrm{SCCM}$ of $\mathrm{H}_{2}$ and $\mathrm{Ar}$ each from (a) $5 \mathrm{~nm}$ and (b) $15 \mathrm{~nm}$ thick $\mathrm{Ni}$ films on $\mathrm{SiO}_{2} /$ $\mathrm{Si}(001)$ wafer. (c) and (d) show Ni nanoparticles formed from 5 and $15 \mathrm{~nm}$ thick $\mathrm{Ni}$ films, respectively, under $200 \mathrm{SCCM}$ of Ar only. The Ni nanoparticles in (b) show the flat hexagonal crystalline shapes. The $\mathrm{X}$-ray diffraction spectra from the Ni nanoparticles treated in (e) $\left(\mathrm{Ar}+\mathrm{H}_{2}\right)$ and (f) Ar only atmosphere. The thermal treatment of $\mathrm{Ni}$ film on $\mathrm{SiO}_{2} / \mathrm{Si}(001)$ wafer in $\left(\mathrm{Ar}+\mathrm{H}_{2}\right)$ forms crystalline Ni nanoparticles with the $\mathrm{Ni}(111)$ planes parallel to the substrate. In contrast, (f) the thermal treatment of $\mathrm{Ni}$ film under $\mathrm{Ar}$ only atmosphere makes the nanoparticles oxidized. (g) The size distribution of $\mathrm{Ni}$ particles formed from 5 and $15 \mathrm{~nm}$ thick $\mathrm{Ni}$ films by thermal treatment in $\left(\mathrm{Ar}+\mathrm{H}_{2}\right)$ atmosphere. 
efficient to use $\mathrm{Ni}$ nanoparticles of different sizes at once, for one can reduce the parameter space from four to three dimension. To prepare Ni nanoparticles with broad size distribution, Ni films with thicknesses of 5 and $15 \mathrm{~nm}$ are deposited on $500 \mathrm{~nm}$ thick $\mathrm{SiO}_{2}$ film grown on $\mathrm{Si}(001)$ wafer.

Then the substrates are pretreated at $850{ }^{\circ} \mathrm{C}$ for 30 min with $200 \mathrm{SCCM}$ of $\mathrm{H}_{2}$ and Ar each to form nano-sized $\mathrm{Ni}$ particles. The total pressure in the CVD chamber is always maintained at 1 atmospheric pressure to reduce the possible evaporation of the $\mathrm{Ni}$ particles at high temperature. As shown in Fig. 1(b), most of the $\mathrm{Ni}$ particles made from $15 \mathrm{~nm}$ thick $\mathrm{Ni}$ film have the flat hexagonal shape characteristic of single crystalline phase. The strong $\mathrm{Ni}(111)$ peak in the $\mathrm{X}$-ray diffraction spectrum verifies that the $\mathrm{Ni}$ nanoparticles are crystalline with the $\mathrm{Ni}(111)$ layers parallel to the substrate [Fig. 1(e)] [27]. The Ni particles formed from $5 \mathrm{~nm}$ thick Ni film are sized in the range of $5-30 \mathrm{~nm}$, while those from $15 \mathrm{~nm}$ thick Ni film cover $20-150 \mathrm{~nm}$.

In order to search for the optimal CNT growth condition in three-dimensional parameter space, we selected six growth temperatures of 520, 620, 720, 770, 820, and $920{ }^{\circ} \mathrm{C}$. At each temperature, the flow rate of $\mathrm{C}_{2} \mathrm{H}_{4}$ was varied among the values of 20,50 , 100, 200, and $400 \mathrm{SCCM}$, and the flow rate of $\mathrm{H}_{2}$ and Ar among 50, 100, 200, 400, and 800 SCCM.

\section{Results}

At $520{ }^{\circ} \mathrm{C}$ [Fig. 2(a)], under all the combinations of the flow rates of $\mathrm{C}_{2} \mathrm{H}_{4}$ and $\mathrm{H}_{2}(\mathrm{Ar})$, the CNTs are grown at high density enough to cover the whole substrate, but are short with curly shape judged from the scanning electron microscope images. At 620, 720, and $770{ }^{\circ} \mathrm{C}$ [Figs. 2(b) -(d)], the CNTs are grown long and straighter with very high density. At $820{ }^{\circ} \mathrm{C}$ [Fig. 2(e)], the density of the CNTs is too low to cover

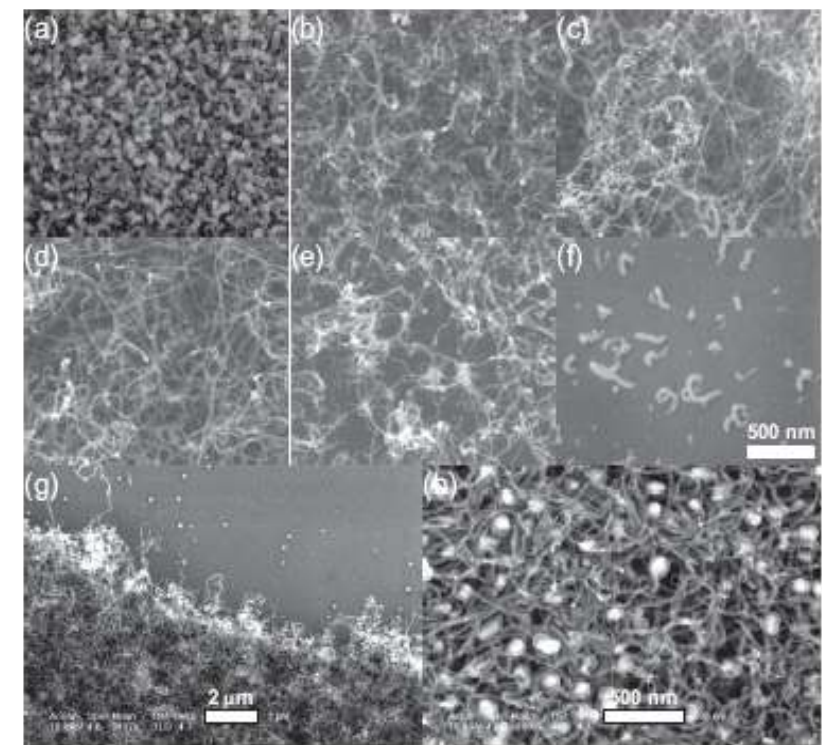

Fig. 2. The SEM images of CNTs grown for $30 \mathrm{~s}$ at (a) 520, (b) 620, (c) 720, (d) 770, (e) 820, and (f) $920{ }^{\circ} \mathrm{C}$. The Ni particles are prepared at $850{ }^{\circ} \mathrm{C}$ for $30 \mathrm{~min}$ from $5 \mathrm{~nm}$ thick $\mathrm{Ni}$ films deposited on $\mathrm{SiO}_{2} / \mathrm{Si}(001)$ wafer under 200 SCCM of $\mathrm{H}_{2}$ and Ar each. During the growth of CNTs, the flow rates of $\mathrm{C}_{2} \mathrm{H}_{4}, \mathrm{H}_{2}$ and Ar are 100, 800, and 800 SCCM, respectively. (g) The SEM image showing the remnant $\mathrm{Ni}$ particles on the substrate after scratch and (h) the bottom view of the scratched CNTs. The CNTs in $(\mathrm{g})$ and (h) are grown at $720{ }^{\circ} \mathrm{C}$ from $\mathrm{Ni}$ particles prepared from $15 \mathrm{~nm}$ thick $\mathrm{Ni}$ films with the supply of 100 SCCM $\mathrm{C}_{2} \mathrm{H}_{4}$ and 800 SCCM H $\mathrm{H}_{2}$ (Ar).

the wafer. At $920{ }^{\circ} \mathrm{C}$ [Fig. 2(f)], the growth probability is very low. Since we are interested only in the $\sim 100 \%$ growth probability of CNTs, we will henceforth focus only on the temperature range between 620 and $770{ }^{\circ} \mathrm{C}$.

The grown CNTs are too dense to directly count the numbers. To quantify the growth probability, we used alternative (indirect) approach. The sample surface was scratched with a sharp pin to turn over the entangled CNTs. The growth probability of CNTs is estimated to be $(1-$ the ratio of the remaining $\mathrm{Ni}$ particles on the substrate after scratch to the total number of $\mathrm{Ni}$ particles before the growth). It is noted that the real growth probability should be higher than the estimated values shown in Fig. 3, for the 
remaining $\mathrm{Ni}$ particles after scratch are either the unreacted ones where no CNTs grew, or the reacted ones which have CNTs grown but were cut from them by the scratch due to the adhesion between the $\mathrm{Ni}$ particles and the substrate [Figs. 2(g) and 2(h)].

At $770{ }^{\circ} \mathrm{C}$, the region of high growth probability above $95 \%$ is narrow with the flow rate of $\mathrm{C}_{2} \mathrm{H}_{4}$ at 100 and 200 SCCM. Also larger CNTs are hardly grown from the larger $\mathrm{Ni}$ particles formed from the $15 \mathrm{~nm}$ thick $\mathrm{Ni}$ film at any flow rates of $\mathrm{C}_{2} \mathrm{H}_{4}$ and $\mathrm{H}_{2}(\mathrm{Ar})$.

At $720{ }^{\circ} \mathrm{C}$, the growth probability is high over wider range of the flow rates of $\mathrm{C}_{2} \mathrm{H}_{4}$ and $\mathrm{H}_{2}(\mathrm{Ar})$. From the smaller Ni particles prepared from $5 \mathrm{~nm}$ thick $\mathrm{Ni}$ film, CNTs grow with high density. In contrast, on the substrate with the larger $\mathrm{Ni}$ particles formed from $15 \mathrm{~nm}$ thick $\mathrm{Ni}$ film, the density of CNTs decreases when the flow rate of $\mathrm{C}_{2} \mathrm{H}_{4}$ is lower than $50 \mathrm{SCCM}$ or that of $\mathrm{H}_{2}$ (Ar) is below 200 SCCM. This shows that with the

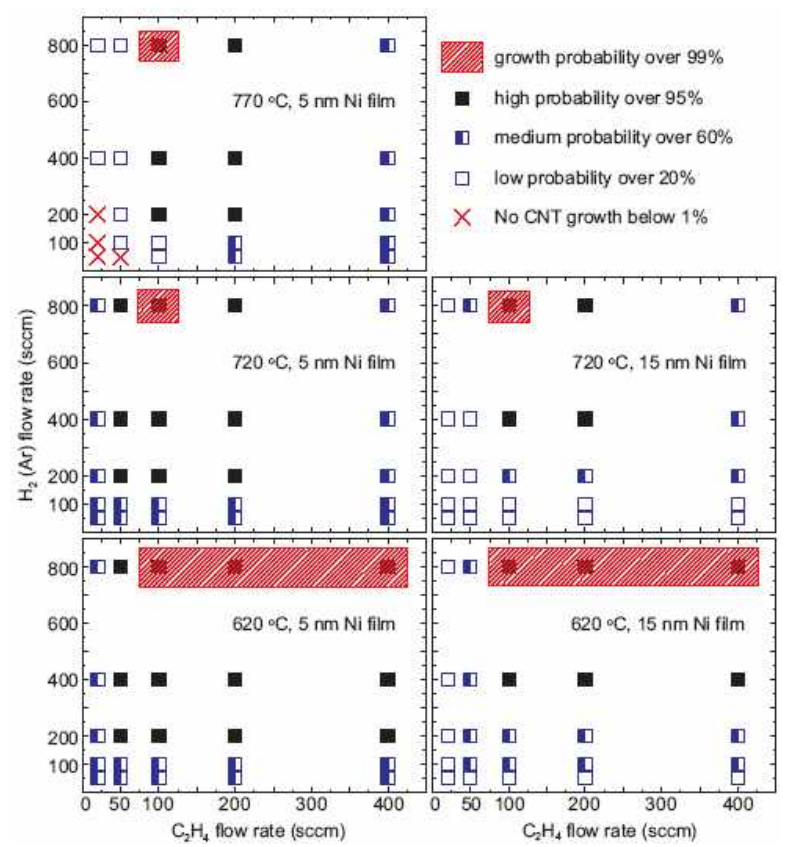

Fig. 3. The growth probabilities of CNTs for various combinations of the flow rates of $\mathrm{C}_{2} \mathrm{H}_{4}$ and $\mathrm{H}_{2}$ ( $\mathrm{Ar}$ ) at 770,720 , and $620{ }^{\circ} \mathrm{C}$. At $770{ }^{\circ} \mathrm{C}$, only the small $\mathrm{Ni}$ particles prepared from $5 \mathrm{~nm}$ thick Ni film grow CNTs with high density. At 720 and $620{ }^{\circ} \mathrm{C}$, Ni particles formed from both 5 and $15 \mathrm{~nm} \mathrm{Ni}$ films grow CNTs with high probability. reduced supply of $\mathrm{C}_{2} \mathrm{H}_{4}$ or $\mathrm{H}_{2}$ (Ar), CNTs are difficult to grow from the larger $\mathrm{Ni}$ particles. The growth probability of CNTs are above 99\% from both of the substrates when the flow rates of $\mathrm{C}_{2} \mathrm{H}_{4}$ and $\mathrm{H}_{2}(\mathrm{Ar})$ are 100 and 800 SCCM, respectively.

At $620{ }^{\circ} \mathrm{C}$, the region of high growth probability increases further over wide range of the flow rates of $\mathrm{C}_{2} \mathrm{H}_{4}$ and $\mathrm{H}_{2}$ (Ar). Decreasing the flow rate of $\mathrm{C}_{2} \mathrm{H}_{4}$ below $100 \mathrm{SCCM}$ or $\mathrm{H}_{2}$ (Ar) below $400 \mathrm{SCCM}$, the growth probability of CNTs starts to decrease. This reduction in the growth probability appears faster in the larger $\mathrm{Ni}$ particles than in the smaller particles, which is reminiscent of the observed tendency at $720{ }^{\circ} \mathrm{C}$.

The distribution of diameter and wall thickness of CNTs grown under optimum conditions (indicated by hatched regions in Fig. 3) are plotted in Fig. 4. At higher temperature, the diameters are distributed around smaller values. Lowering the temperature, the diameter distribution is broadened towards larger values. As to the wall thickness, the CNTs grown at higher temperature are thinner than those grown at lower temperature as shown in Fig. 4(d). The larger and thicker CNTs are difficult to grow at higher
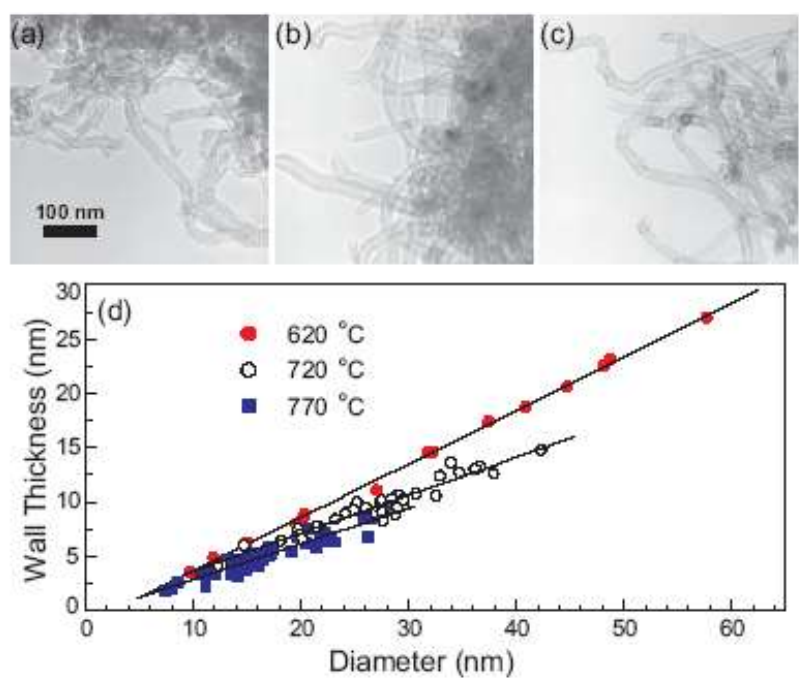

Fig. 4. The TEM images of the CNTs grown at (a) 620, (b) 720 , and (c) $770{ }^{\circ} \mathrm{C}$. (d) The relations between diameters and wall thicknesses of CNTs grown at 620, 720, and $770{ }^{\circ} \mathrm{C}$. 
temperatures, since the supply of $\mathrm{C}$ atoms to the catalytic seeds is inefficient due to the self-pyrolysis of $\mathrm{C}_{2} \mathrm{H}_{4}$ or increased turbulence. The same mechanism applies to the observed narrowness of conditions for guaranteeing high density CNT growth at elevated temperatures (e.g., $770{ }^{\circ} \mathrm{C}$ ).

After finding the optimal growth conditions, we tried to grow an individual MWNT from each $\mathrm{Ni}$ nanoparticle. For this purpose, a two-dimensional square array of $\mathrm{Ni}$ particles with the diameter of 250 $\mathrm{nm}$ is fabricated on the $\mathrm{SiO}_{2} / \mathrm{Si}(001)$ wafer with periodicity of $1 \mathrm{~m}$ as shown in Fig. 5(a). The substrate is ion-milled to reduce the size of $\mathrm{Ni}$ particles, and etched by $\mathrm{HCl}$ to remove the $\mathrm{Ni}$ shreds created by ion-milling. With this procedure, the size of $\mathrm{Ni}$ particles can be reduced to below $20 \mathrm{~nm}$ in diameter as shown in Fig. 5(b). The CNTs are grown from the array of $\mathrm{Ni}$ nanoparticles for $20 \mathrm{~s}$ at $720{ }^{\circ} \mathrm{C}$
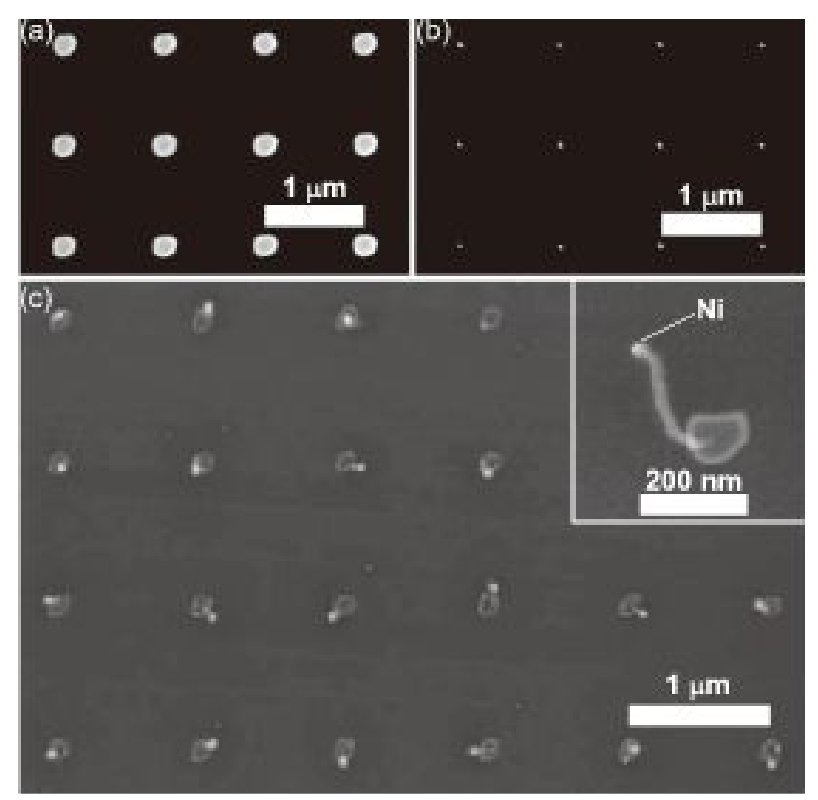

Fig. 5. (a) The $250 \mathrm{~nm}$ Ni particles deposited on $\mathrm{SiO}_{2} / \mathrm{Si}$ wafer with periodicity of $1 \mathrm{~m}$ in $\mathrm{x}^{-}$and $\mathrm{y}-$ directions. (b) The substrate is ion-milled to reduce the size of $\mathrm{Ni}$ particles down to below 20 $\mathrm{nm}$, and etched by $\mathrm{HCl}$ to remove the $\mathrm{Ni}$ shreds. (c) The individual CNT with the diameter smaller than $20 \mathrm{~nm}$ grown from each isolated Ni particle. Inset in (c) shows a magnified image of a CNT-Ni nanoparticle pair. with the flow rates of $50 \mathrm{SCCM}_{2} \mathrm{H}_{4}$ and $800 \mathrm{SCCM}$ $\mathrm{H}_{2}$ ( $\mathrm{Ar}$ ). This growth condition is slightly off the optimum to slow down the growth speed of CNTs. Figure 5(c) demonstrates that an individual CNT is indeed grown from each $\mathrm{Ni}$ particle. The growth probability of the CNTs is found to be almost $100 \%$ by inspecting several hundreds of $\mathrm{Ni}$ particles. The CNT with the diameter smaller than $20 \mathrm{~nm}$ is grown out from the substrate.

All the processes including deposition of $250 \mathrm{~nm} \mathrm{Ni}$ dots, ion-milling, etching by $\mathrm{HCl}$, and thermal CVD, can be performed on a wafer scale. Thus the CNT growing method introduced in this work is applicable to plant individual MWNT smaller than $20 \mathrm{~nm}$ at arbitrary position over wide area of the substrate. In combination with the aligning method of CNTs by external electric field [16-18] or focused ion beam [28], we will be able to control the direction of MWNTs on a wafer scale. The grown MWNTs can be subsequently thinned controllably in diameter down to SWNTs by burning stepwise from the outer layers $[29,30]$. Such a controllability would enable the usage of CNTs as the tips of scanning probe microscopes or essential components in the integrated CNT-based devices in the future.

\section{Conclusions}

We have found the optimal conditions of the thermal CVD growth of CNTs from nano-sized $\mathrm{Ni}$ particles from exhaustive search in the three-dimensional parameter space of the growth temperature and the flow rates of $\mathrm{C}_{2} \mathrm{H}_{4}$ and $\mathrm{H}_{2} / \mathrm{Ar}$. With the optimal growth conditions, adjusting the total pressure, and using the two-dimensionally ordered $\mathrm{Ni}$ particles, we have demonstrated that CNTs can be grown with controlled diameter, position, and length on a wafer scale. Since current optical lithography for Si technology can fabricate $\sim 50 \mathrm{~nm}$ half-pitch and is targeting at 
sub-20 nm in near future, we will be able to fabricate nanoparticles of transition metals smaller than $\sim 5 \mathrm{~nm}$ by ion-milling and chemical etching. By combining such a technological advance and the control technology developed in this work, diameter and length controlled SWNTs would be grown at desired locations in a specified direction over wide area of $\mathrm{Si}$ wafer, which will be the essential element for the CNT-based integrated devices.

\section{Acknowledgments}

This work is supported by Ministry of Science and Technology of Korea through the Creative Research Initiative.

\section{References}

[1] S. Iijima, Nature (London) 354, 56 (1991).

[2] M. Bockrath, D.H. Cobden, P.L. McEuen, N.G. Chopra, A. Zettl, A. Thess, and R.E. Smalley, Science 275, 1922 (1997).

[3] J.W.G. Wildoer, L.C. Venema, A.G. Rinzler, R.E. Smalley, and C. Dekker, Nature 391, 59 (1998).

[4] T.W. Odom, J.-L. Huang, P. Kim, and C.M. Lieber, Nature 391, 62 (1998).

[5] S.J. Tans, A.R.M. Verschueren, and C. Dekker, Nature 393, 49 (1998).

[6] T. Rueckes, K. Kim, E. Joselevich, G.Y. Tseng, C.-L. Cheung, and C.M. Lieber, Science 289, 94 (2000).

[7] H.W.C. Postma, T. Teepen, Z. Yao, M. Grifoni, and C. Dekker, Science 293, 76 (2001).

[8] V. Derycke, R. Martel, J. Appenzeller, and P. Avouris, Nano Lett. 1, 453 (2001).

[9] A. Bachtold, P. Hadley, T. Nakanishi, and C. Dekker, Science 294, 1317 (2001).

[10] A. Javey, H. Kim, M. Brink, Q. Wang, A. Ural,
J. Guo, P. Mcintyre, P. Mceuen, M. Lundstrom, and H. Dai, Nature Mater. 1, 241 (2002).

[11] J. Liu, M.J. Casavant, M. Cox, D.A. Wlaters, P. Boul, W. Lu, A.J. Rimberg, K.A. Smith, D.T. Colbert, and R.E. Smalley, Chem. Phys. Lett. 303, 125 (1999).

[12] J.C. Lewenstein, T.P. Burgin, A. Ribayrol, L.A. Nagahara, and R.K. Tsui, Nano Lett. 2, 443 (2002).

[13] S.G. Rao, L. Huang, W. Setyawan, and S. Hong, Nature 425, 36 (2003).

[14] L.A. Nagahara, I. Amlani, J. Lewenstein, and R.K. Tsui, Appl. Phys. Lett. 80, 3826 (2002).

[15] R. Krupke, F. Hennrich, H.B. Weber, M.M. Kappes, and H.V. Lohneysen, Nano Lett. 3, 1019 (2003).

[16] Y. Zhang, A. Chang, J. Cao, Q. Wang, W. Kim, Y. Li, N. Morris, E. Yenilmez, J. Kong, and H. Dai, Appl. Phys. Lett. 79, 3155 (2001).

[17] E. Joselevich and C.M. Lieber, Nano Lett. 2, 1137 (2002).

[18] Y.-T. Jang, J.-H. Ahn, B.-K. Ju, and Y.-H. Lee, Solid State Commun. 126, 305 (2003).

[19] Y. Li, J. Liu, Y. Wang, and Z.L. Wang, Chem. Mater. 13, 1008 (2001).

[20] Y. Li, W. Kim, Y. Zhang, M. Rolandi, D. Wang, and H. Dai, J. Phys. Chem. B 105, 11424 (2001).

[21] C.L. Cheung, A. Kurtz, H. Park, and C.M. Lieber, J. Phys. Chem. B 106, 2429 (2002).

[22] S.N. Zaretskiy, Y.-K. Hong, D.H. Ha, J.-H. Yoon, J. Cheon, and J.-Y. Koo, Chem. Phys. Lett. 372, 300 (2003).

[23] Y.-K. Hong, J.H. Bahng, G. Lee, H. Kim, W. Kim, S. Lee, J.-Y. Koo, J.-I. Park, W. Lee, and J. Cheon, Chem. Comm., 3034 (2003).

[24] V. Semet, V.T. Binh, P. Vincent, D. Guillot, K.B.K. Teo, M. Chhowalla, G.A.J. Amaratunga, W.I. Milne, P. Legagneux, and D. Pribat, Appl. Phys. Lett. 81, 343 (2002).

[25] Q. Ye, A.M. Cassell, H. Liu, K.-J. Chao, J. Han, and M. Meyyappan, Nano Lett. 4, 1301 (2004).

[26] A. Javey and H. Dai, J. Am. Chem. Soc. 127, 11942 
(2005).

[27] The crystallinity almost disappears from the nanoparticles formed in Ar only atmosphere due to oxidation. It was reported that the growth probability of CNTs from pure Co nanoparticles was higher than that from oxidized Co nanoparticles [22].
[28] B.C. Park, K.Y. Jung, W.Y. Song, B. O, and S.J. Ahn, Adv. Mater. 18, 95 (2006).

[29] P.G. Collins, M.S. Arnold, and P. Avouris, Science 292, 706 (2001).

[30] J.Y. Huang, S. Chen, S.H. Jo, Z. Wang, D.X. Han, G. Chen, M.S. Dresselhaus, and Z.F. Ren, Phys. Rev. Lett. 94, 236802 (2005). 


\section{$\mathrm{Ni}$ 나노입자의 배열을 이용한 다중벽 탄소나노튜브의 제어된 성장}

지승묵 ${ }^{1}$ 이태진 ${ }^{1}$ 방재호 ${ }^{2}$, 홍영규 $^{2}$, 김한철 ${ }^{2}$ 하동한 ${ }^{2}$, 김창수 $^{2}$, 구자용 $^{2 *}$

1강원대학교 물리학과, 춘천 790-784

2 한국표준과학연구원, 대전 유성우체국 사서함 102 호

(2008년 6월 9일 받음, 2008년 8월 28일 수정, 2008년 8월 28일 확정)

화학기상증착법과 $\mathrm{Ni}$ 나노입자 배열을 이용한 탄소나노튜브의 최적 성장 조건을 연구했다. $\mathrm{Ni}$ 입자의 크기를 변화시키는 방 법으로 탄소나노튜브의 직경을 $20 \mathrm{~nm}$ 이하까지 제어할 수 있었다. 개별 $\mathrm{Ni}$ 입자의 크기와 위치는 기존의 식각법 등을 이용 하여 웨이퍼 수준의 대면적에서 연속적으로 제어가 가능하였다. 성장온도, 탄소원, 희석가스 등의 비율을 최적화 함으로써 $\mathrm{SiO}_{2} / \mathrm{Si}$ 웨이퍼의 넓은 면적에서 각 $\mathrm{Ni}$ 입자로부터 단 한 개씩의 탄소나노튜브가 $100 \%$ 확률로 성장 가능하다는 것을 보였다. 탄소나노튜브의 위치, 직경, 벽두께 등의 특성들은 성장조건을 조정하여 제어가능하다는 것을 보였다.

주제어: 탄소나노튜브, 제어된 성장, 나노입자, 화학기상증착

* [전자우편] : koojayon@kriss.re.kr 